\section{COUNCIL DECISIONS}

A report on the Council meeting held in London on $20 / 21$ March 1986 will be given in the May issue.

\section{Changes to the Constitution}

In the light of previous experience, the Executive Committee had concluded that it would be in the interests of the Society if the fiveyear limit rule governing service on the Committee could at times be waived when it came to the choice of President. This could help in preserving continuity and could assure a more logical progession through the Committee while still leaving the necessary flexibility to take account of the changing circumstances of members.

On the invitation of the Executive, Council therefore agreed to amend ARTICLE 19 of the Constitution subject to any material objection of the Members. Paragraph 2 would begin:

2. Members may be re-elected provided that:

a) they do not serve for more than five years consecutively except that a member having served for five consecutive years in the Executive Committee may be elected President for the following year and may be re-elected for a final term the year after.
New Collaborating Society

Council has approved the admission of the 1800-strong Canadian Association of Physicists (CAP) as a Collaborating Society.

Members of CAP are, in consequence, entitled from now on to become Individual Members of EPS on payment of an annual membership fee of SFR 55.- or CAN\$ 40.-. Applications should be addressed to the Secretariat in Geneva.

\section{IOM Delegates}

As a result of the postal elections held over the past weeks, the following have been elected as IOM delegates to Council for a period of four years:

Philippe Choquard, ETH, Zurich

Jozef Devreese, University of Antwerp

Hans Ryde, University of Lund and as first alternate:

Ivan Ulehla, Charles University, Prague.

\section{Executive Committee 1986/87}

Council elected to the Executive Committee for $1986 / 87$ the following: President: W. Buckel, Karlsruhe Vice-President: R.A. Ricci, Padova Secretary: W.J. Merz, Zurich Vice-Secretary: N. Kroo, Budapest Treasurer: E.W.A. Lingeman,

$$
\text { Amsterdam }
$$

Vice-Treasurer: J.-M. Gilles, Namur Members: L. Cohen, London
B. Dreyfus, Grenoble
O.V. Lounasmaa, Espoo
J. Pozhela, Vilnius
E. Skrzypczak, Warsaw

The retiring President, Prof. G.H. Stafford had intimated that he would not offer himself for re-election and Profs. D. Kuhn, the retiring Treasurer and K.K. Rebane, Member, having completed five years in office were no longer eligible for re-election.

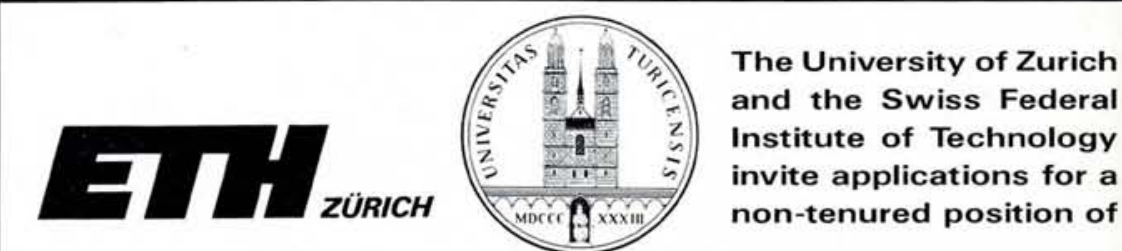

\section{Assistant Professor of Crystallography}

Duties of the new professor include basic crystallography for students in natural sciences and materials sciences as well as advanced courses for crystallography students. Special expertise in theoretical crystallography is desired.

The successful applicant will have an advanced university degree and internationally recognized contributions in physical crystallography. An ability to teach at all university levels and a will to cooperate with colleagues in chemical crystallography and mineralogy are expected.

Applications with curriculum vitae and a list of publications should be submitted before May 31, 1986 to:

Dekanat der Philosophischen Fakultät II,

Universität Zürich, Rämistrasse 71, CH-8006 Zürich.
EPS Divisions, Sections and Group

Astronomy and Astrophysics Division Solar Physics Section

Atomic and Molecular Physics Division Atomic Spectroscopy Section Chemical Physics

Electronic and Atomic Collisions

Molecular Physics

Computational Physics Group

Condensed Matter Division

Liquids Section

Low Temperature Physics Section

Macromolecular Physics

Magnetism

Metal Physics

Semiconductors and Insulators Surfaces and Interfaces

High Energy \& Particle Physics Division

Interdiv. Group on Physics for Development

Nuclear Physics Division

Optics Division

Plasma Physics Division

Quantum Electronics Division
Europhysics News is the official journal of the European Physical Society which comprises 29 National Societies, Academies and Group, over 3500 Individual Mem bers and 73 Associate Members, Governing bodies of EPS are the General Meeting, Council and an elected Executive Committee responsible for detailed policy. EPS promotes the collaboration of physicists through. out Europe, organising and harmonising conferences and publications, improving physics education, encou raging physics applications, awarding scholarships to sponsored schools in Erice. EPS publishes in addition to Europhysics News, Europhys. Conf. Abs., Eur. Ed News, Europhys. Lett. (in partnership with national societies), Eur. J. Phys. lin partnership with The UK Inst. of Phys.). Individual Members receive Europhys. News free of charge (price to institutions: Sw.Fr. 90 (a), rebates on the price of many publications and on conference fees. Annual EPS membership fee for Individual Members belonging to an EPS member society is: Sw.Fr. 44.; independent members: Sw.Fr. 132. members of a Collaborating Society: Sw.Fr. 55. (\$26).
Editor: E.N. Shaw

Editorial Board

K. Appert, A. Baratoff, B. Jacrot

F. James, M. Mayor, J. Muller

Editorial and Advertising Office at the EPS Secretariat

Address: EUROPEAN PHYSICAL SOCIETY P. O. Box 69 , $\mathrm{CH}-1213$ Petit-Lancy 2 Switzerland

Telephone: Geneva (22) 931130

Telex: 428024 eps ch

Cables: europhys genève

Printed by: Pfirter frères s CH-1213 Petit-Lancy/Switzerland 